\title{
Impact of Indian Dramas on Interaction behavior of female
}

\author{
Zahid Yousaf (PhD) ${ }^{1,}$ Arshad (PhD) ${ }^{2,}$ Ammarah (M.S $)^{3,}$ \\ ${ }^{1}$ Assistant Professor/Head, ${ }^{2}$ Assistant Professor, \\ ${ }^{1,2,3}$ Centre for Media and Communication Studies, University of Gujrat, Post code 50700 Gujrat, Punjab, \\ Pakistan)
}

\begin{abstract}
Cable television is playing a vital role in Pakistani society. In Pakistan people mostly spend their time on watching Indian media as compare to other channels. In this study researchers find out the Indian dramas impact on people social interaction. Therefore, researcher selected target population female age group from 16 to 35 years from village Sehowal, Sialkot. While cultivation theory selected as theoretical framework that addresses the effects of television viewing on attitude and behavior of viewers. The study concluded that the viewing patterns of respondents indicated that their free evening time, which was previously used for social and family bonding, is now spent in front of the cable television especially for Star Plus dramas.
\end{abstract}

Keywords: Cable Television, Culture, Social Interaction, Dramas, Effects, Cultivate

\section{Introduction:}

In modern age Private Media is playing very important role in Pakistani society. Media presenting alien culture therefore, Pakistani society norms and values are blending to alien culture. Cable television viewership is more due to easily availability of connection, low-priced television and Varity of contents. It has become a frequent household facility for the everyone in pakistan. As Schiller $(1976)^{1}$ confirms 'importing programs is importing lifestyles and exposure to foreign television programs may transform the values of youth.' Concerns over the impact/effects of media always reinforce whenever a new communication technology is introduced in the society because technology always has positive or negative impact. Pakistani people spend most of their time on watching Indian media especially they like star plus as compare to other channels. Females neglect their domestic duties and spend their time on star plus dramas. It is better to say that star plus is become a family member of Pakistani society. People like to discuss dramas on dining tables, during travel and even on job places star plus with them.We can't ignore that the star plus is one reason of divorces in Pakistani because when Females ignore their duties domestic crisis develop as the result and some stories end on divorce (Family cases which are pending in family courts). This study investigates the impact of language, interaction and dressing of Indian dramas on the female of village Sehowal.

Cables television is communication technology which is cheap affordable and assessable throughout the day, making it possible for the viewer to choose from a wide Varity of channels and program from local to foreign channels, with the availability of television and cable, a viewer has a huge choice ranging from local to international channels around the clock, with the availability of so many channels and so many foreign culture on cable specially Indian, it's really easy for a viewer to fall victim of new traditions and culture. The word culture has many different meanings. However, for anthropologists and other behavioral scientists, culture is the full range of learned human behavior patterns. Culture is a powerful human tool for survival, but it is a fragile phenomenon. It is constantly changing and easily lost because it exists only in our mind (Tylor, 1920) ${ }^{2}$.

\section{Social Interaction:}

Social interaction is a part of Pakistan's culture. Families in Pakistan welcomed people at their homes arrange gatherings, meet frequently with their friends, family, neighbors and relatives to interact, spend leisure time, and share their feelings, emotions and family matters with each other. Proud nations take pride in promoting and expanding their language. Cable channels are affecting the language of Pakistani people, now people feel proud when they speak English and Hindi, and those who cannot speak English frequently try to incorporate English words in their regional and Urdu language to leave good impression on others. Traditions play an important part in every culture as well as formation of cultural identification. Impact of foreign traditions that are being introduced through media has great influence on our religious traditions. Majority of the people admitted that they follow Hindu traditions.

\section{Objectives of the Study:}

The main objective of the study is the impact of Indian drama language, interaction and dressing on the females of village Sehowal district Sialkot. 
- To understand the demographic characteristics of viewers and the amount of time spend watching the television and how much is viewer affected by Indian dramas?

- To find whether exposure of Indian dramas modify the lifestyle of viewers or not? Here are some objectives...

- To check the interaction of females with others due to the influence of Indian dramas.

- Find out relationship between viewing of cable television and its effects on Language and interaction pattern among women.

Hypothesis

H1: Whether or not Indian media trying to cultivate their culture in our society?

H2: Whether or not these Indian dramas change social interaction in family/friends?

\section{Significance of the study:}

This research is important in understanding the impact of Indian dramas on culture and social interaction on Pakistani society and can recommend the media policy maker to come up with changes in police. Today the time is very valuable to realize the importance of own culture and also must be aware about the impacts of alien culture. If today we ignore this important issue the new coming generation will not be familiar to their identification. So we must be realizing the importance of time if we want to maintain our dignity. Similarly, the viewers can also be guided to preserve their own culture. Policies can be made by the media authorities with the help of this study, to prevent broadcast of programs responsible for the glorification of Indian culture in Pakistani society.

\section{Literature Review}

Webster and Lichty $(1991)^{3}$ further concluded that the intensity of group viewing, paying attentions and frequency and duration to watch various programs are the attributes and essence of housewives in subcontinent. Indian satellite television networks particularly Star Plus catches the overseas formats and tries with the Hindi versions. "Kyonkaisaasbhikabhibahu this" (Indian satellite channel Star Plus famous soap opera) was most prominent soap opera in South Asia which has won the attention and time of most of the housewives of this region as it did not only provided the entertainment through its story, casts and acting but also allegorically paints the issues of every home of India and Pakistan.

Saba $(1996)^{4}$ searched that due to electronic media social life are change now people wants to discuss different dramas at meal time. They prefer to watch dramas rather than to perform their social activities. Due to media the hesitation between student and students is revoked. They understand the problem to one and other. They copy the style of their favorite actor or actress and their link with their norms is cutting now. Aqira (2000) ${ }^{5}$ percepts that females prefer to watch satellite channels due to fashion and male watch satellite channels for news and current affairs programs. Social lives of people have been changed due to said activity they want to watch TV rather than interaction with people. People want to adopt modern life style as they saw on TV and they try to speak English. Fatima (2000) ${ }^{6}$ in her thesis "Effects of satellite channels (Zee TV) on Lahore middle class" concluded that Zee TV is gaining popularity over PTV and other channels among middle class and our social values are changing slowly and steadily. She said that her research proved that it might be difficult to invade a new concept or diffuse new traditions in a society, but systemic and regular propaganda can bring change in thoughts and beliefs of the public.

Malik $(2003)^{7}$ stated that "the impact of cable television transmission on the residents of Multan". She concludes it is obvious that the viewers who spend time watching cable television transmission, their routine and activities are affected. Inter-individual communication has decreased. Results of the survey indicated that powerful culture traditions of alien culture, particularly Indian culture, are getting popularity due to cable television transmission. Moreover, this transmission is promoting the modern way of life.

Zainab (2004) ${ }^{8}$ scrutinizes that after the arrival of satellite dish people have a lot of choices about the selection of TV channels. Family members gathered around the dining table and involve in the discussion about Indian dramas and films. Pakistanis have begun to adopt language and life style of Indian dramas and films even the length of dresses are change now. Dancing trend is also increasing in our society if any Indian celebrities act in any ad is a evident the credibility of the product. Aslam $(2006)^{9}$ points out that Indian media puts influence on Pakistani marriage ceremonies. People enjoy when they perform useless customs like shoes hidden, lap filing etc. all these ceremonies are not the part of Muslim culture although these ceremonies were performing in the past. But due to the Indian dramas especially these kind of ceremonies become more popular as comp are to past.

Mahvish $^{10} \&$ Gulam $^{11}$ (2006) point out the influence of highly developed countries of the world on Pakistani society. These impacts change our dressing, eating stuff and our room setting. Social relationships are effecting by drama culture. Routine life is also changing in negative way on the name of fashion. Pakistani 
media and people especially female are copying star plus culture. The life style of females become like Indian females. On the other hand Pakistani drama makers trying to show star plus culture in their dramas sari culture also increasing. But a lot of people realize that these dramas are destroying our culture and cause different domestic problems.

Anthony $(2011)^{12}$ found that much stringer culture which was presented in a vivid way highly adoptable and often admirable in the Indian tale serials. Majority of women responded the attraction toward hair style dress and dished presented and worn Indian models and tried to do and look the same way. With dish antenna society was adoption new ways trends and lifestyle.

Qamar, Zafar and Shawar (2012) ${ }^{13}$, conducted survey and discussed in their research The Impact assessment Of Indian culture on Pakistani Society in FAISALABAD, The objectives of the study were to assess the impacts of Indian culture on Pakistani tangible and intangible culture (norms \& values); and also to identify the role of mass media in promoting Indian culture in Pakistani society. The results of the study demonstrated that all of the respondents were well aware of the hostile and adverse impacts of Indian culture on Pakistani society. Such as our language, dressing, life style, performing and visual art, values and norms are highly influenced by Indian culture.

This study has used Cultivation Theory by George Gerbner as a guide in exploring the consequences/effects. Under guidance of this theory, this study may be able to emerge as a new theory. Essentially, the theory states that heavy exposure to mass media namely television creates and cultivates attitudes more consistent with a media conjured version of reality than with what actual reality is. They emphasize the effects of television viewing on attitude rather than the behavior of viewers. Heavy watching of television is seen as 'cultivating' attitudes which are more consistent with the world of television programs than with the everyday world. Cultivation theorists are best known for their study of television and viewers and, in particular, for a focus on the topic of violence. However, some studies have also considered other mass media from this perspective and have dealt with topics such as gender roles, age groups, ethnic groups and political attitudes.

Gerbner argues that television has become the central cultural arm of the American society. "Television set has become a key member of the family, the one who tells most of the stories most of the time." Gerbner and his associates (Gerbner, Gross, Morgan and Signorelli, 1994) ${ }^{14}$ have written that there are two types of television viewers: heavy and light viewers. For heavy viewers, television virtually monopolizes and subsumes other sources of information, ideas and consciousness. Gerbner says that the effect of all this exposure to the same messages produces what he calls cultivation or the teaching of a common worldview, common roles and common values. Gerbner presents research supporting "Cultivation Theory" that is based on comparison between heavy and light television viewers. Gerbner analyzed answers to question posted in surveys and found that heavy and light television viewers typically give different answers. Further, heavy television viewers often give answers that are closer to the way the world is portrayed on television.

\section{Research Methodology}

The chapter of Research Methodology gives an account of the research method used for the study, target population, sampling method, sampled population, tool of research, data collection procedures, and research questions and framing of the questionnaire. In this study, survey method has been applied to obtain the data that is quantitative in nature from population. The survey has aided the researcher in collecting information directly from the cable television viewers so that a proper analysis could be made by comparing their lives. The changes in their lives have hence figured out through the information provided on a quantitative scale.

Wimmer and Dominick (1993) "a sample is the subset of the population that is taken to be the representative of the entire population". In the light of the above definition, total population of this study comprises all female cable television viewers aged 16 to 35 years and residing in village Sehowl. The researcher preferred this age group of women for the study because it is the most vibrant, active and dynamic part of their lives. It was not feasible for the researcher to approach the total population therefore sampling technique was applied. In this research, Questionnaire' schedule (verbal interview based on questionnaire) was selected as a tool for data collection. Questionnaires were consisting of 24 questions and lickert scale was used by researcher. Numerical value assigned to each option (from 1, Strongly Agree to 5, Strongly Disagree).

\section{Variables of research:}

In survey research we check relationship between the variables. In present study Indian dramas are in depended variable and the impact of these dramas on females is depended variable. The independent variable Indian dramas contains on the most watched Indian channels in village Sehowal like star plus, Zee TV , colors and Life ok. The dependent variable is social interaction/culture which is influencing by these drama's language and contents in the females of village Sehowal district Sialkot. 


\section{Findings}

\begin{tabular}{|c|c|c|c|c|c|c|}
\hline & & & \multicolumn{3}{|c|}{ Age } & \multirow[t]{2}{*}{ Total } \\
\hline Table no 1 & & & $16-20$ & $21-24$ & $25-30$ & \\
\hline \multirow{6}{*}{$\begin{array}{l}\text { What time do } \\
\text { you like to watch } \\
\text { Indian dramas? }\end{array}$} & \multirow[t]{2}{*}{ From morning till 2 p.m. } & Count & 3 & 3 & 5 & 11 \\
\hline & & $\%$ of Total & $3.0 \%$ & $3.0 \%$ & $5.0 \%$ & $11.0 \%$ \\
\hline & \multirow[t]{2}{*}{ From 2 p.m. to 7 p.m. } & Count & 5 & 6 & 2 & 13 \\
\hline & & $\%$ of Total & $5.0 \%$ & $6.0 \%$ & $2.0 \%$ & $13.0 \%$ \\
\hline & \multirow[t]{2}{*}{ After 7} & Count & 37 & 29 & 10 & 76 \\
\hline & & $\%$ of Total & $37.0 \%$ & $29.0 \%$ & $10.0 \%$ & $76.0 \%$ \\
\hline \multirow{2}{*}{\multicolumn{2}{|c|}{ Total }} & Count & 45 & 38 & 17 & 100 \\
\hline & & $\%$ of Total & $45.0 \%$ & $38.0 \%$ & $17.0 \%$ & $100.0 \%$ \\
\hline
\end{tabular}

Table 1 shows that $76 \%$ Respondent like to watch Indian dramas after 7 p.m. between them $37 \%$ belong to 16-20 age groups, 29\% belongs to 21-24 age groups and 10\% belongs to 25-30 age groups.13\% Respondent like to watch Indian dramas from 2 p.m. to 7 p.m. between them 5\% belong to $16-20$ age groups, $6 \%$ belongs to 21-24 age groups and 2\% belongs to $25-30$ age groups. $11 \%$ Respondent like to watch Indian dramas from morning till 2 p.m. between them 3\% belong to 16-20 age groups, 3\% belongs to $21-24$ age groups and 5\% belongs to 25-30 age groups.

\begin{tabular}{|c|c|c|c|c|c|c|}
\hline & & & \multicolumn{3}{|c|}{ Age } & \multirow[t]{2}{*}{ Total } \\
\hline Table no 2 & & & $16-20$ & $21-24$ & $25-30$ & \\
\hline \multirow{10}{*}{$\begin{array}{l}\text { Is Indian } \\
\text { dramas cause } \\
\text { hurdles in your } \\
\text { domestic } \\
\text { activities? }\end{array}$} & \multirow[t]{2}{*}{ Agree } & Count & 10 & 6 & 2 & 18 \\
\hline & & $\%$ of Total & $10.0 \%$ & $6.0 \%$ & $2.0 \%$ & $18.0 \%$ \\
\hline & \multirow[t]{2}{*}{ strongly agree } & Count & 13 & 6 & 4 & 23 \\
\hline & & $\%$ of Total & $13.0 \%$ & $6.0 \%$ & $4.0 \%$ & $23.0 \%$ \\
\hline & \multirow[t]{2}{*}{ Disagree } & Count & 15 & 13 & 6 & 34 \\
\hline & & $\%$ of Total & $15.0 \%$ & $13.0 \%$ & $6.0 \%$ & $34.0 \%$ \\
\hline & \multirow[t]{2}{*}{ strongly disagree } & Count & 6 & 11 & 4 & 21 \\
\hline & & $\%$ of Total & $6.0 \%$ & $11.0 \%$ & $4.0 \%$ & $21.0 \%$ \\
\hline & \multirow[t]{2}{*}{ Not decided } & Count & 1 & 2 & 1 & 4 \\
\hline & & $\%$ of Total & $1.0 \%$ & $2.0 \%$ & $1.0 \%$ & $4.0 \%$ \\
\hline \multirow{2}{*}{\multicolumn{2}{|c|}{ Total }} & Count & 45 & 38 & 17 & 100 \\
\hline & & $\%$ of Total & $45.0 \%$ & $38.0 \%$ & $17.0 \%$ & $100.0 \%$ \\
\hline
\end{tabular}

Table 2 shows that 34\% Respondent disagree that Indian dramas causes hurdles in their domestic activities between them $15 \%$ belongs to $16-20$ age, $13 \%$ belongs to $21-24$ age groups and 6\% belongs to 25-30 age groups. $23 \%$ Respondent strongly agree between them $13 \%$ belongs to $16-20$ age, $6 \%$ belongs to $21-24$ age groups and $4 \%$ belongs to $25-30$ age groups. $21 \%$ Respondent strongly dis agree between them $6 \%$ belongs to $16-20$ age, $11 \%$ belongs to $21-24$ age groups and $4 \%$ belongs to $25-30$ age groups.18 \% Respondent agree between them $10 \%$ belongs to $16-20$ age, $6 \%$ belongs to $21-24$ age groups and $2 \%$ belongs to $25-30$ age groups. $4 \%$ Respondent has not decided.

\begin{tabular}{|c|c|c|c|c|c|c|}
\hline & & & \multicolumn{3}{|c|}{ Age } & \multirow[t]{2}{*}{ Total } \\
\hline Table no 3 & & & $16-20$ & $21-24$ & $25-30$ & \\
\hline \multirow{10}{*}{$\begin{array}{l}\text { Interaction with } \\
\text { neighbor decreasing } \\
\text { due to watching Indian } \\
\text { drams? }\end{array}$} & \multirow[t]{2}{*}{ Agree } & Count & 4 & 7 & 3 & 14 \\
\hline & & $\%$ of Total & $4.0 \%$ & $7.0 \%$ & $3.0 \%$ & $14.0 \%$ \\
\hline & \multirow[t]{2}{*}{ Strongly agree } & Count & 5 & 3 & 5 & 13 \\
\hline & & $\%$ of Total & $5.0 \%$ & $3.0 \%$ & $5.0 \%$ & $13.0 \%$ \\
\hline & \multirow[t]{2}{*}{ Disagree } & Count & 22 & 10 & 3 & 35 \\
\hline & & $\%$ of Total & $22.0 \%$ & $10.0 \%$ & $3.0 \%$ & $35.0 \%$ \\
\hline & \multirow[t]{2}{*}{ Strongly disagree } & Count & 14 & 13 & 5 & 32 \\
\hline & & $\%$ of Total & $14.0 \%$ & $13.0 \%$ & $5.0 \%$ & $32.0 \%$ \\
\hline & \multirow[t]{2}{*}{ not decided } & Count & 1 & 3 & 2 & 6 \\
\hline & & $\%$ of Total & $1.0 \%$ & $3.0 \%$ & $2.0 \%$ & $6.0 \%$ \\
\hline \multirow{2}{*}{\multicolumn{2}{|c|}{ Total }} & Count & 46 & 36 & 18 & 100 \\
\hline & & $\%$ of Total & $46.0 \%$ & $36.0 \%$ & $18.0 \%$ & $100.0 \%$ \\
\hline
\end{tabular}

Table 3 shows 35\% Respondent disagree that their interaction with neighbor decreasing due to watching Indian dramas between them $22 \%$ belong to 16-20 age groups, 19\% belongs to 21-24 age groups and $3 \%$ belongs to $25-30$ age groups.32 \% Respondent strongly disagree between them $14 \%$ belong to $16-20$ age 
groups, $13 \%$ belongs to $21-24$ age groups and 5\% belongs to $25-30$ age groups. $14 \%$ Respondent agree between them $4 \%$ belong to 16-20 age groups, $7 \%$ belongs to 21-24 age groups and 3\% belongs to 25-30 age groups.

$13 \%$ Respondent strongly agree between them 5\% belong to $16-20$ age groups, 3\% belongs to $21-24$ age groups and 5\% belongs to 25-30 age groups. $6 \%$ Respondent have no decided between them 1\% belong to 16-20 age groups and $2 \%$ belongs to $25-30$ age groups and $3 \%$ belong to $21-24$ age.

\begin{tabular}{|c|c|c|c|c|c|c|}
\hline & & & \multicolumn{3}{|c|}{ Age } & \multirow[t]{2}{*}{ Total } \\
\hline Table no 4 & & & $16-20$ & $21-24$ & $25-30$ & \\
\hline \multirow{10}{*}{$\begin{array}{l}\text { Interaction with } \\
\text { friends decreasing due } \\
\text { to watching Indian } \\
\text { drams? }\end{array}$} & \multirow[t]{2}{*}{ Agree } & Count & 5 & 4 & 6 & 15 \\
\hline & & $\%$ of Total & $5.0 \%$ & $4.0 \%$ & $6.0 \%$ & $15.0 \%$ \\
\hline & \multirow[t]{2}{*}{ strongly agree } & Count & 3 & 4 & 1 & 8 \\
\hline & & $\%$ of Total & $3.0 \%$ & $4.0 \%$ & $1.0 \%$ & $8.0 \%$ \\
\hline & \multirow[t]{2}{*}{ Disagree } & Count & 24 & 13 & 6 & 43 \\
\hline & & $\%$ of Total & $24.0 \%$ & $13.0 \%$ & $6.0 \%$ & $43.0 \%$ \\
\hline & \multirow[t]{2}{*}{ strongly disagree } & Count & 10 & 17 & 4 & 31 \\
\hline & & $\%$ of Total & $10.0 \%$ & $17.0 \%$ & $4.0 \%$ & $31.0 \%$ \\
\hline & \multirow[t]{2}{*}{ Not decided } & Count & 3 & 0 & 0 & 3 \\
\hline & & $\%$ of Total & $3.0 \%$ & $.0 \%$ & $.0 \%$ & $3.0 \%$ \\
\hline \multirow{2}{*}{\multicolumn{2}{|c|}{ Total }} & Count & 45 & 38 & 17 & 100 \\
\hline & & $\%$ of Total & $45.0 \%$ & $38.0 \%$ & $17.0 \%$ & $100.0 \%$ \\
\hline
\end{tabular}

Table 4 shows $43 \%$ Respondent disagree that their interaction with friends decreasing due to watching Indian dramas between them $24 \%$ belong to 16-20 age groups, $13 \%$ belongs to $21-24$ age groups and 6\% belongs to $25-30$ age groups. $31 \%$ Respondent strongly disagree between them $10 \%$ belong to $16-20$ age groups, $17 \%$ belongs to $21-24$ age groups and $4 \%$ belongs to $25-30$ age groups. 15\% Respondent agree between them 5\% belong to 16-20 age groups, $4 \%$ belongs to 21-24 age groups and 6\% belongs to 25-30 age groups.8 \% Respondent strongly agree between them $3 \%$ belong to $16-20$ age groups, $4 \%$ belongs to $21-24$ age groups and $1 \%$ belongs to $25-30$ age groups.3\% Respondent have no decided .

\begin{tabular}{|c|c|c|c|c|c|c|}
\hline & & & \multicolumn{3}{|c|}{ Age } & \multirow[t]{2}{*}{ Total } \\
\hline Table no 5 & & & $16-20$ & $21-24$ & $25-30$ & \\
\hline \multirow{8}{*}{$\begin{array}{l}\text { I don't like to visit to } \\
\text { others home at the time } \\
\text { of watching of Indian } \\
\text { dramas? }\end{array}$} & \multirow[t]{2}{*}{ Agree } & Count & 11 & 7 & 4 & 22 \\
\hline & & $\%$ of Total & $11.0 \%$ & $7.0 \%$ & $4.0 \%$ & $22.0 \%$ \\
\hline & \multirow[t]{2}{*}{ strongly agree } & Count & 9 & 9 & 3 & 21 \\
\hline & & $\%$ of Total & $9.0 \%$ & $9.0 \%$ & $3.0 \%$ & $21.0 \%$ \\
\hline & \multirow[t]{2}{*}{ Disagree } & Count & 22 & 16 & 9 & 47 \\
\hline & & $\%$ of Total & $22.0 \%$ & $16.0 \%$ & $9.0 \%$ & $47.0 \%$ \\
\hline & \multirow[t]{2}{*}{ strongly disagree } & Count & 3 & 6 & 1 & 10 \\
\hline & & $\%$ of Total & $3.0 \%$ & $6.0 \%$ & $1.0 \%$ & $10.0 \%$ \\
\hline \multirow{2}{*}{\multicolumn{2}{|c|}{ Total }} & Count & 45 & 38 & 17 & 100 \\
\hline & & $\%$ of Total & $45.0 \%$ & $38.0 \%$ & $17.0 \%$ & $100.0 \%$ \\
\hline
\end{tabular}

Table 5 shows that $47 \%$ Respondent disagree that they do not like to visit to others home at the time of watching Indian dramas between them $22 \%$ belongs to 16-20 age, 16\% belongs to 21-24 age and 9\% belongs to 25-30 age group. $22 \%$ Respondent agree that they do not like to visit to others home at the time of watching Indian dramas between them $11 \%$ belongs to $16-20$ age, $7 \%$ belongs to $21-24$ age and $4 \%$ belongs to $25-30$ age group. $21 \%$ Respondent strongly agree that they do not like to visit to others home at the time of watching Indian dramas between them 9\% belongs to 16-20 age, $9 \%$ belongs to $21-24$ age and 3\% belongs to $25-30$ age group. $10 \%$ Respondent strongly dis agree between them $3 \%$ belongs to $16-20$ age, $6 \%$ belongs to $21-24$ age and $1 \%$ belongs to $25-30$ age group.

\begin{tabular}{|c|c|c|c|c|c|c|}
\hline & & & \multicolumn{3}{|c|}{ Age } & \multirow[t]{2}{*}{ Total } \\
\hline Table no 6 & & & $16-20$ & $21-24$ & $25-30$ & \\
\hline \multirow{8}{*}{$\begin{array}{l}\text { My outing with my } \\
\text { family decreasing these } \\
\text { days due to this } \\
\text { reason? }\end{array}$} & \multirow[t]{2}{*}{ Agree } & Count & 9 & 6 & 2 & 17 \\
\hline & & $\%$ of Total & $9.0 \%$ & $6.0 \%$ & $2.0 \%$ & $17.0 \%$ \\
\hline & \multirow[t]{2}{*}{ strongly agree } & Count & 7 & 6 & 3 & 16 \\
\hline & & $\%$ of Total & $7.0 \%$ & $6.0 \%$ & $3.0 \%$ & $16.0 \%$ \\
\hline & \multirow[t]{2}{*}{ Disagree } & Count & 21 & 21 & 7 & 49 \\
\hline & & $\%$ of Total & $21.0 \%$ & $21.0 \%$ & $7.0 \%$ & $49.0 \%$ \\
\hline & \multirow[t]{2}{*}{ strongly disagree } & Count & 8 & 5 & 5 & 18 \\
\hline & & $\%$ of Total & $8.0 \%$ & $5.0 \%$ & $5.0 \%$ & $18.0 \%$ \\
\hline \multirow{2}{*}{\multicolumn{2}{|c|}{ Total }} & Count & 45 & 38 & 17 & 100 \\
\hline & & $\%$ of Total & $45.0 \%$ & $38.0 \%$ & $17.0 \%$ & $100.0 \%$ \\
\hline
\end{tabular}


Table 6 shows that $49 \%$ Respondent disagree that their outing with their family decreasing due to watching Indian dramas between them $21 \%$ belongs to 16-20 and 21-24 age groups and 17\% belongs to 25-30 age group. $18 \%$ Respondent strongly disagree between them $8 \%$ belongs to $16-20$ age, $5 \%$ belongs to $21-24$ age groups and 5\% belongs to 25-30 age group. $17 \%$ Respondent agree that their outing with their family decreasing due to watching Indian dramas between them 9\% belongs to 16-20 age, 6\% 21-24 age groups and $2 \%$ belongs to $25-30$ age group. $16 \%$ Respondent strongly agree between them $7 \%$ belongs to $16-20$ age, $6 \%$ 21-24 age groups and 3\% belongs to 25-30 age groups.

\section{Discussion:}

The findings of a survey by Rahim (1994) ${ }^{16}$ on "Impact of Cable on Television and Video Viewing in Hyderabad" also support the results of this study. He concludes; "Average time spent on watching television is 5.36 hours per day in each household. More females watch entertainment programs on television. Although there is no significant variation of choice regarding news between Door Darshan and cable television but cable television is preferred for entertainment programs and movies."

According to the results favorite watching time, it is concluded that the starting time of dramas on Star Plus is 7:00 pm to 11:00 pm. These viewing patterns of respondents indicated that their free evening time, which was previously used for social and family bonding, is now spent in front of the cable television. There are slight changes due to the impact of Indian dramas on their domestic activities only $23 \%$ females strongly agree that their domestic activities disturbed due to watching Indian dramas. Social interaction was the next factor to be measured. It tried was determined if time spend with family, friends and neighbor it squeezed because cable television. Results show that there are slight changes on decreasing the interaction of females of village Sehowal due to watching of Indian dramas with their relatives, friends and neighbors. Respondent agree that their Interaction decreasing with their relatives due to Indian dramas and also agree that Indian dramas causing hurdles in decreasing the social interaction with friends.

Another factor is to visiting others and someone visit to your home, majority respondent disagree that they do not have disturbed to visit to others while watching Indian dramas. While some Respondent strongly agree that they got disturbed when someone visit to their home while watching Indian dramas. It's mean Indian dramas have effect on females even in village area. Slight changes occur in females life Indian dramas create more interest in females even they got disturbed when someone came their home.

\section{Conclusion}

Many national researches supported the results of this factor of the study. A national study by Malik (2003) on "The impact of cable television transmission on the residents of Multan" supports the results of this study by concluding that powerful cultural traditions, particularly Indian culture, are getting popularity due to cable television transmission. In the case of language this study presents that respondents use Hindi language words and they have learned Hindi words evidentially from Indian dramas. According to the result of the study, in the case of interaction, there is minor changing occurs that is the interaction with relatives, friends and neighbor in village Sehowal district Sialkot.

\section{References}

[1]. Schiller, Herbert. (1976). Communication and Cultural Domination. International Arts and Sciences Press. New York : North Broadway

[2]. Tylor, E. B. (1920). Primitive culture. New York: J.P. Putnam's sons. pp. 410

[3]. Webster, J. G., \& Lichty, L. W. (1991). Ratings analysis: Theory and practice. Hillsdale, NJ: Erlbaum

[4]. Saba, Noor (1996) "Impacts of electronic media on co-education" M.A Thesis, Mass Communication, B.Z.U. Multan

[5]. Aqira, Irum (2000) "Effectiveness of satellite channels and impacts on the viewers of Multan city" M.A Thesis, Mass Communication, B.Z.U. Multan

[6]. Fatima,N. (2000) Effects of satellite channels (Zee TV) on Lahore moddle class. Unpublished Master's thesis, department of sociology, university of Punjab, Lahore, Pakistan.

[7]. Malik, N. (2003). The impact of cable TV transmission on the residents of Multan. Unpublished master's thesis, department of Mass Communication, Bahauddin Zakariya University, Multan. Pakistan.

[8]. Zinab, Mahmood (2004) "The Bollywood Effect is Reema the next Rani?" retrieved from http://www.chowk.com/articles/7967 on $11 / 4 / 2010$.

[9]. Aslam, Jamal (2006) "Colorful Indian Marriage Ceremonies" retrieved from http://www.muslim-marriage-guide.com/indianmarriage-customs.html on 03/05/2010.

[10]. Mahwish, Faima, (2006) "Changing Life Style in Pakistan" retrieved from http://www.hamariweb.com/article.aspx?id=1168 on $03 / 04 / 2010$

[11]. Gulam, Mustafa (2006) "Revival of Pakistani Dramas" retrieved from http://www.thoughts.com/Roshni_com/blog/revival-ofpakistani-dramas-471805/ on 30/04/2010

[12]. Anthony, Z (2011) "Impact of Indian Television Channels on Pakistani Society: A Case Study of Islamabad Society" This Dissertation is submitted in the Department of Mass Communication, Allama Iqbal Open University, Islamabad, pp.4-9

[13]. Qamar, M., Asim, M., Shawar, D.and Zafar, M. I. (2012) "The Impacts Assessment of Indian Culture on Pakistani Society in Faisalabad" International Journal of Research in Social Sciences and Humanities, Vol. 1, No. V, pp. 53-62 
[14]. Gerbner, G., Gross, L., Morgan, M., \&Signorielli, N. (1994).Growing up with television: The cultivation perspective. Norwood: Apex Publications.

[15]. Wimmer, R. D., \& Dominick, J. R. (1993). Qualitative Research Methods. Mass Media Research. (pp. 63-64, 139-161, 342, 512). California: Wadsworth Publishing Company.

[16]. Rahim, A. (1994). Impact of cable TV on television and video viewing in Hyderabad: A

[17]. Survey. Media Asia: an Asian mass communication quarterly, 21(1), 15-20.

[18]. Malik, N. (2003). The impact of cable TV transmission on the residents of Multan. Unpublished master's thesis, department of Mass Communication, Bahauddin Zakariya University, Multan. Pakistan. 